\title{
Agronomic and nutritional responses of Carajas elephant grass fertilized with protected and non-protected urea
}

\section{Respostas agronômicas e nutricionais de capim elefante Carajas adubado com ureia protegida e não protegida}

\author{
Francisco Gleyson da Silveira Alves ${ }^{1 *}$; Maria Socorro de Souza Carneiro ${ }^{2}$; \\ Ricardo Loiola Edvan'; Magno José Duarte Cândido²; Rafael Nogueira Furtado; \\ Elzânia Sales Pereira²; Luiz Barreto de Morais Neto ${ }^{5}$; Rute Ribeiro Marins Mota ${ }^{6}$; \\ Keuven dos Santos Nascimento ${ }^{7}$
}

\begin{abstract}
The objective of this study was to assess the agronomic and nutritional responses of the elephant grass cultivar Carajas when subjected to fertilization with protected and conventional urea. A randomized block design with $4 \times 2+1$ factorial arrangement was adopted. The treatments consisted of four doses $\left(100,200,400\right.$, and $\left.800 \mathrm{~kg} \mathrm{~N} \mathrm{ha}^{-1}\right)$, two nitrogen sources (conventional and protected urea), and one additional treatment without fertilization. The experiment was carried out from October 2015 to March 2016, in a semi-arid region with a dystrophic yellow latosol type soil. The application of conventional urea was done with each of the multiple cuts performed per year, whereas the protected urea was applied in a single dose. Total senescence rate (TSR), leaf and stem elongation, height, tiller density, total forage biomass, green leaf and stem biomass, and dry matter all increased with increasing $\mathrm{N}$ doses. However, the phyllochron, live material/dead material ratio, and agronomic efficiency all decreased with $\mathrm{N}$ increasing dose. Plants fertilized with protected urea presented greater TSR and phyllochron. Mineral matter content was higher in plants fertilized with conventional urea. Neutral detergent fiber content was maximized at a dose of $437.63 \mathrm{~kg} \mathrm{~N} \mathrm{ha}^{-1}$. The protected urea resulted in a higher value of leaf/stem ratio at the $400 \mathrm{~kg} \mathrm{~N}^{-1}$ dose, whereas ether extract and crude protein at the $800 \mathrm{~kg} \mathrm{~N} \mathrm{ha}^{-1}$. With application of conventional urea, the highest crude protein value occurred at a dose of $100 \mathrm{~kg} \mathrm{~N}$ $\mathrm{ha}^{-1}$. The morphogenesis, structure, production, and chemical composition of elephant grass 'Carajas' were all positively influenced when nitrogen doses were increased, with the recommended optimal dose for use being $400 \mathrm{~kg} \mathrm{~N} \mathrm{ha}^{-1}$ for both sources. The use of protected urea is recommended because of its slow release and need for only a single application.
\end{abstract}

Key words: Biomass components. Biomass flow. Bromatology. Pennisetum purpureum $\times$ Pennisetum glaucum. Protected urea. Urea.

\footnotetext{
'Discente, Curso de Doutorado em Zootecnia, Universidade Federal do Ceará, UFC, Fortaleza, CE, Brasil. E-mail: gleysonufc54@ gmail.com

2 Prof ${ }^{\text {s. Dr }}$., Departamento de Zootecnia, UFC, CE, Brasil. E-mail: msocorro@ufc.br; magno@ufc.br; elzania@hotmail.com

3 Prof. Dr., Departamento de Zootecnia, Universidade Federal do Piauí, UFPI, Bom Jesus, PI, Brasil. E-mail: edvan@ufpi.edu.br

4 Pós-Doutorando, Dr., Departamento de Zootecnia, UFC, Fortaleza, CE, Brasil. E-mail: rafaelnfurtado@yahoo.com.br

5 Dr. em Zootecnia, Integral Agroindustrial, Fortaleza, CE, Brasil. E-mail: luiz_bmneto@yahoo.com.br

6 Discente, Curso de Mestrado em Zootecnia, UFPI, Bom Jesus, PI, Brasil. E-mail: rute.marinszootc@yahoo.com.br

Discente, Curso de Bacharelado em Zootecnia, UFPI, Bom Jesus, PI, Brasil. E-mail: keuvensantos03@gmail.com

* Author for correspondence
} 


\section{Resumo}

Objetivou-se avaliar as respostas agronômicas e nutricionais do capim elefante cultivar Carajas submetido à adubação com ureia protegida e convencional. Adotou-se o delineamento em blocos casualizado com arranjo fatorial $4 \times 2+1$. Os tratamentos constituíram-se por quatro doses $(100 ; 200$; 400 e $800 \mathrm{~kg} \mathrm{~N} \mathrm{ha}^{-1}$ ) e duas fontes de nitrogênio (ureia convencional e protegida) e um tratamento adicional sem fertilidade. $\mathrm{O}$ experimento foi conduzido durante os meses de outubro de 2015 a março de 2016, em uma região com clima semiárido e em um solo do tipo latossolo amarelo distrófico. A aplicação da ureia convencional foi de acordo com o número de cortes por ano e a ureia protegida foi em dose única. As taxas de senescência total (TST), alongamento de folha e colmo, altura, densidade de perfilhos, biomassa de forragem total, biomassa de lâmina verde, de colmo e matéria seca elevaramse com aumento das doses de $\mathrm{N}$. O filocrono, a relação material vivo/morto e a eficiência agronômica reduziram. As plantas adubadas com ureia protegida apresentaram maior TST e filocrono. A matéria mineral foi maior em plantas adubadas com a ureia convencional. Fibra em detergente neutro apresentou valor máximo na dose $437,63 \mathrm{~kg} \mathrm{~N} \mathrm{ha}^{-1}$. A ureia protegida apresentou maior valor para relação folha/ colmo na dose $400 \mathrm{~kg} \mathrm{~N} \mathrm{ha}^{-1}$, enquanto extrato etéreo e proteína bruta na dose $800 \mathrm{~kg} \mathrm{~N}^{1}$. Maiores valores de proteína bruta foram observados em plantas adubadas com a ureia convencional na dose 100 $\mathrm{kg} \mathrm{N} \mathrm{ha}^{-1}$. A morfogênese, estrutura, produção e composição química do capim-elefante cv. Carajas são influenciadas positivamente quando as doses de nitrogênio foram aumentadas, sendo recomendado o uso da dose $400 \mathrm{~kg} \mathrm{~N} \mathrm{ha}^{-1}$ para ambas as fontes. Recomenda-se utilizar a ureia protegida por apresentar liberação lenta e única aplicação.

Palavras-chave: Bromatologia. Componentes da biomassa. Fluxo de biomassa. Pennisetum purpureum $x$ Pennisetum glaucum. Ureia. Ureia protegida.

\section{Introduction}

The factors that most influence animal productivity in semi-arid regions are variations in the quality and the production of forage due to the irregularity of rains. The use of irrigated forage areas is one of the alternative means used to alleviate this problem of variation in animal performance throughout the year, with elephant grass (Pennisetum purpureum) being a prominent and often-used forage species. Among the elephant grass cultivars currently on the market, the cultivar Carajas (Pennisetum purpureum $\times$ P. glaucum) is noteworthy due to its ability to be propagated by seeds and because it presents high dry matter production.

A relevant factor that affects livestock production indices and economic performance is the use of nitrogen fertilization (EUCLIDES et al., 2007; SANTOS et al., 2008). Nitrogen fertilization has positive effects on the production and nutritive value of forage, including improving plant growth rate rapidly restoring leaf area index, increasing assimilation rate, and increasing crude protein content (PACIULLO et al., 1998; ANDRADE et al., 2003). In addition, nitrogen fertilization positively affects the morphogenic and productive characteristics of the grass (MOTA et al., 2010; MARTUSCELLO et al., 2015)

The main source of nitrogen used in Brazil is urea, because of its lower cost per unit of nitrogen when compared to other sources, and also because of its high nitrogen content. However, this N source is rapidly hydrolyzed, which favors losses by volatilization in the form of ammonia $\left(\mathrm{NH}_{3}\right)$ and reduces use efficiency of urea by the crops (TASCA et al., 2011).

To reduce nitrogen losses and increase the use efficiency of urea, some alternatives have been developed, such as the use of urease and nitrification inhibitors and polymer coatings, mainly of polyurethane and polyolefins (BLAYLOCK, 2007). These strategies to reduce nitrogen losses lead to a decrease in $\mathrm{NH}_{3}$ losses by volatilization because they block the active site of the enzyme urease, which 
is responsible for the hydrolysis of the molecule of urea into $\mathrm{NH}_{3}$ (OKUMURA; MARIANO, 2012).

The increase in nitrogen fertilizer efficiency, reduction in environmental problems caused by high rates of ammonium and nitrate nitrification, lower frequency of application, and reduction in production costs are some advantages of the use of polymer-protected urea (SOARES, 2011). Polymerprotected urea undergoes less loss of nitrogen by leaching and volatilization, which allows the frequency of its application to be reduced. The coating controls the release of nitrogen, where the polymers act as a semipermeable membrane that mainly allows only water to move through the coating (JONES et al., 2007).

Due to its slow release, protected urea can be applied in a single dose, causing no loss in the responses of the plant to nitrogen fertilization. Based on this information, the objective of this study was to assess the agronomic and nutritional responses of the elephant grass cultivar Carajas subjected to fertilization with protected and conventional urea

\section{Material and Methods}

In this study, an experiment was conducted at the Experimental Farm of the Federal University of Piauí (UFPI), located in Alvorada do Gurgueia, Brazil. The city has latitude $8^{\circ} 22^{\prime} 30^{\prime \prime}$ South, $43^{\circ}$ $50^{\prime} 48^{\prime \prime}$ West, with $239 \mathrm{~m}$ altitude. Total rainfall is around 900 to $1200 \mathrm{~mm}$ per year (VIANA et al., 2010). The climate of the region is semi-arid with a yellow distrofic latosol type soil. The experiment was carried out from October 2015 to March 2016.

The experimental design consisted of four randomized blocks with a $4 \times 2+1$ factorial arrangement, which consisted of four nitrogen doses $\left(100,200,400\right.$, and $800 \mathrm{~kg} \mathrm{ha}^{-1}$ year $\left.^{-1}\right)$ and two nitrogen sources (conventional urea and urea protected by copper and boron polymers), plus one additional treatment without fertilization. The protected urea used was FH Nitro Mais, developed by Fertilizantes Heringer.

Fertilization with the nitrogen source protected by polymers was done with the application of a single dose, whereas fertilization with the conventional urea was dependent on the number of cuts performed per year, such that it was carried out after each cut. Cuts were performed every 40 days at a height of $20 \mathrm{~cm}$ from the soil, according to the recommendations of the company MATSUDA $\AA$ for elephant grass 'Carajas'. Four harvests were performed during the evaluation period.

As the polymer-protected urea $(44.6 \% \mathrm{~N})$ used provided $0.4 \%$ boron and $0.15 \%$ copper, in the treatments receiving conventional urea fertilization $(45 \% \mathrm{~N})$ the same amounts of boron and copper were also applied. Boron and copper were applied as boric acid $\left(\mathrm{H}_{3} \mathrm{BO}_{3}\right)$ and as copper sulfate $(\mathrm{CuSO} 4)$, diluted in one liter of water and applied in the corresponding plots.

Before the beginning of the experiment a representative soil sample of the area was collected from the $0-20 \mathrm{~cm}$ depth layer for analyses and chemical characterization. Composite sample were sent to the Soil Laboratory of the Federal University of Piauí - Campus Professor Cinobelina Elvas (UFPI - CPCE), in Bom Jesus city, Piauí state, Brazil. The values obtained in the soil analyses were: $\mathrm{pH}\left(\mathrm{H}_{2} \mathrm{O}\right)$ of 5.40; $\mathrm{P}$ of $9.6 \mathrm{mg} \mathrm{dm}^{-3}$; $\mathrm{K}$ of $21.19 \mathrm{mg} \mathrm{dm}^{-3}$; $\mathrm{Ca}$ of $2.4 \mathrm{cmol} \mathrm{dm}^{-3} ; \mathrm{Mg}$ of $0.6 \mathrm{cmol} \mathrm{dm}^{-3} ; \mathrm{Al}$ of $0.0 \mathrm{cmol} \mathrm{dm}^{-3} ; \mathrm{H}+\mathrm{AL}$ of $3.5 \mathrm{cmol} \mathrm{dm}^{-3}$; sum of bases of $3.1 \mathrm{cmol} \mathrm{dm}^{-3}$; effective CTC of $3.1 \mathrm{cmol}$ $\mathrm{dm}^{-3}$; CTC at $\mathrm{pH} 7.0$ of $6.5 \mathrm{cmol} \mathrm{dm}^{-3}$; base saturation of $46.8 \%$; and aluminum saturation of $0.0 \%$. Based on these results, soil correction and fertilization were performed according to Vilela et al. (2002). Soil correction was done with dolomitic limestone (PRNT 80\%) to bring soil saturation levels to 60\%. For fertilization, $20.8 \mathrm{~g}$ of phosphorus per linear meter (simple superphosphate, $18 \%$ of $\mathrm{P}_{2} \mathrm{O}_{5}$ ) and $3.44 \mathrm{~g}$ of potassium per linear meter (potassium chloride, $48 \%$ of $\mathrm{K}_{2} \mathrm{O}$ ) were applied. 
The experimental area was composed of a planting of elephant grass 'Carajas.' The area was established in 2013. Planting was carried out in line, and for each linear meter $0.64 \mathrm{~g}$ of grass seeds were used, according to recommendations of the company MATSUDA $^{\circledR}$. In October 2015 a uniform cut was performed at $20 \mathrm{~cm}$ above the soil surface, the urea treatments were applied, and then irrigation by 10 $\mathrm{mm}$ water blade was carried out every three days on each plot. Weed control was done sporadically when necessary by manual weeding.

The experimental area was set up as four blocks, consisting of nine plots within each block. Each experimental plot had an area of $4 \mathrm{~m}^{2}(4 \mathrm{~m}$ width $\times 1$ $m$ length), with five rows of plants per plot; for data collection, only the plants in the central line were used. The plots were separated by unused spaces of one meter between the plots of each block, and two meters separation between the blocks.

For the measurement of biomass flow, a clump of grass was randomly selected in each plot, in which three tillers were placed that were marked with colored rings. Evaluations began three days after the cut and were repeated every three days. The appearance, elongation, and senescence of leaf blades and the elongation of stems were recorded. The length of the expanded leaf blade was determined by measuring these from the ligule to the apex. The length of the emergent leaf blade was measured from its apex to the ligule of the last exposed leaf. The length of the senescent portion was obtained by calculating the difference between the total length of the leaf blade and the green portion of the same leaf. The length of the stem was measured as the distance to the ligule of the last exposed leaf from the base of the tiller marked near the soil. From these data the following indices were also calculated: leaf elongation rate (LER); stem elongation rate (SER), referring to the daily average elongation of the sheaths and true stem of the tiller; total leaf senescence rate (TSR); and phyllochron.
Various measurements of the grass canopy structure were made before each cut. Canopy height was measured at 10 random points within each experimental plot with a retractable, graduated rod as the distance between the ground and the curvature of the highest leaf touched by the tip of the rod (SILVA et al., 2015). Population density of tillers per linear meter was determined by counting the number of live tillers present in a clump in the central line of each plot. The live material/ dead material ratio (LM/DM) was obtained by dividing the dry weight of the green biomass by the weight of the dead biomass. The leaf/stem ratio (L/S) was obtained by dividing the dry weight of the leaf blades by the dry weight of the stem and sheath. The total forage biomass (TFB), green leaf biomass (GLB), and green stem biomass (GSB) were estimated from samples collected in a linear meter, which were separated into living and dead material, and then the living material of the leaf blades and stem were separated. These samples were conditioned in paper bags, weighed, and placed in a forced ventilation oven at $55^{\circ} \mathrm{C}$ until a constant weight was obtained, and then weighed again. The biomasses were quantified from the total fresh weight and from the different fractions. The agronomic efficiency (AE) of nitrogen fertilization was calculated as the difference of the green forage biomass with or without fertilization divided by the dose of nitrogen applied.

Samples were ground up in a Wiley mill using a 1-mm screen sieve. For the determination of chemical composition, the methods of the Analytical Methods Association of Official Analytical Chemists (AOAC, 1990) for dry matter (DM, method $n^{\circ}$ 930.15), total nitrogen (method $n^{\circ} 984.13$ ), mineral matter (MM, method $n^{\circ}$ 942.05), and ether extract (EE, method $n^{\circ} 920.39$ ) were used. Neutral detergent fiber (NDF) contents were determined according to the methodology described by Van Soest et al. (1991). Analyses were performed at the Animal Nutrition Laboratory of the Federal University of 
Ceara. The crude protein content (CP) was obtained by multiplying the total nitrogen content by 6.25 .

The resulting data were tested using analysis of variance (ANOVA), mean comparison tests, and regression analysis. Significant differences among factors (e.g., treatments) and their interactions were concluded with ANOVA if the F-test resulted in $\mathrm{p}<$ 0.05 . The averages were compared by Tukey's test ( $\mathrm{p}$ $<0.05)$. In the regression analysis, model selection was based on the significance of the linear and quadratic coefficients, using significance threshold of $p<0.05$. Statistical analyses were carried out using SISVAR ${ }^{\circledR}$ version 5.0 software, developed by the Federal University of Lavras (FERREIRA, 2011).

\section{Results and Discussion}

There was no significant interaction between nitrogen dose and source type $(p>0.05)$ for any of the morphogenetic traits evaluated. The $\mathrm{N}$ doses significantly influenced all characteristics ( $\mathrm{p}<$ 0.0001 ), however, and the types of $\mathrm{N}$ sources only significantly affected phyllochron $(p=0.0078)$ and total senescence rate $(p=0.0385)$.

The leaf elongation rate (LER) showed a positive linear response to increasing nitrogen dose (Table 1). This response is attributable to the effect of nitrogen on the physiological processes of the plant and the resultant higher production of cells. According to Skinner and Nelson (1995), leaf elongation is restricted to the dividing zone at the base of the expanding leaf, and this zone is a site with great demand for nutrients, mainly nitrogen. Lobo et al. (2014), evaluating the response of elephant grass 'Pioneiro' to doses of nitrogen $(100,200$, 300 , and $400 \mathrm{~kg} \mathrm{ha}^{-1}$ year $^{-1}$ ) observed an increase in LER of $17.67 \%$ between the lowest and the highest fertilization doses they used. In the present study, an increase of $58.99 \%$ was observed between the treatment with no fertilization and that with a dose of $800 \mathrm{~kg} \mathrm{~N} \mathrm{ha}^{-1}$ year-1. $^{-1}$

Table 1. Morphogenetic responses of elephant grass 'Carajas' to different doses and sources of nitrogen fertilization.

\begin{tabular}{|c|c|c|c|c|c|c|c|}
\hline \multirow{2}{*}{ Variables } & \multicolumn{5}{|c|}{ N Doses $\left(\mathrm{kg} \mathrm{ha}^{-1}\right.$ year $\left.^{-1}\right)$} & \multirow[t]{2}{*}{ MSE } & \multirow[t]{2}{*}{ F Value } \\
\hline & 0 & 100 & 200 & 400 & 800 & & \\
\hline \multirow{2}{*}{$\operatorname{LER}\left(\mathrm{cm} \mathrm{til}^{-1}\right.$ day $\left.^{-1}\right)$} & 4.69 & 6.29 & 6.88 & 7.59 & 8.44 & 0.14 & $<0.0001^{*}$ \\
\hline & \multicolumn{6}{|c|}{$\hat{\mathrm{Y}}=5.5581+0.0041 \times \mathrm{R}^{2}=0.82$} & \\
\hline \multirow{2}{*}{ Phyllochron (day) } & 6.77 & 6.58 & 5.88 & 5.28 & 4.88 & 0.11 & $<0.0001^{*}$ \\
\hline & \multicolumn{6}{|c|}{$\hat{Y}=6.6071-0.0024 x R^{2}=0.88$} & \\
\hline \multirow{2}{*}{ SER (cm til ${ }^{-1}$ day $\left.^{-1}\right)$} & 0.27 & 0.26 & 0.34 & 0.44 & 0.59 & 0.02 & $<0.0001^{*}$ \\
\hline & \multicolumn{6}{|c|}{$\hat{Y}=0.2516+0.0004 x R^{2}=0.98$} & \\
\hline \multirow{4}{*}{$\operatorname{TSR}\left(\mathrm{cm} \mathrm{til}^{-1}\right.$ day $\left.^{-1}\right)$} & 0.72 & 1.02 & 1.14 & 1.24 & 1.35 & 0.02 & $<0.0001 *$ \\
\hline & \multicolumn{6}{|c|}{$\hat{Y}=0.8903+0.0007 x R^{2}=0.75$} & \\
\hline & \multicolumn{5}{|c|}{ Source } & MSE & F Value \\
\hline & \multicolumn{3}{|c|}{$\mathrm{U}$} & \multicolumn{2}{|l|}{$\mathrm{PU}$} & & \\
\hline Phy (day) & \multicolumn{2}{|c|}{$5.75 b$} & & \multicolumn{2}{|l|}{$6.02 \mathrm{a}$} & 0.07 & $0.0078 *$ \\
\hline $\operatorname{TSR}\left(\mathrm{cm} \mathrm{til}^{-1}\right.$ day $\left.^{-1}\right)$ & \multicolumn{2}{|c|}{$1.07 \mathrm{~b}$} & & \multicolumn{2}{|l|}{$1.11 \mathrm{a}$} & 0.01 & $0.0385^{*}$ \\
\hline
\end{tabular}

LER: leaf elongation rate; SER: stem elongation rate; TSR: senescence rate; Phy: phyllochron. U: conventional urea; PU: protected urea. Means with the same lowercase letter in the row did not differ according to Tukey's test $(\mathrm{p}>0.05)$. MSE: mean standard error; *: significant at $\mathrm{p}<0.05$. 
The phyllochron decreased linearly with increasing nitrogen dose, showing a reduction of 0.0024 days $^{1}$ leaf $^{-1}$ for each $1 \mathrm{~kg}$ increase of nitrogen and with the longest value observed in the treatment without fertilization (Table 1). The decrease of the phyllochron with nitrogen fertilization occurred due to the positive effect of nitrogen on growth rate. Nitrogen fertilization confers a great capacity for regrowth to plants, so after cutting or defoliation a faster recovery of the photosynthetic apparatus occurs, which can improve the overall recovery and survival of the plant community. Moreover, with greater availability of nitrogen the physiological processes of the plant are accelerated and there is a higher leaf appearance rate, and thus consequently a smaller phyllochron (MARTUSCELLO etal., 2006). Martuscello et al. (2015) also observed a negative response of phyllochron of Massai grass (Panicum maximum 'Massai') to nitrogen enrichment and found that phyllochron values ranged from 12.48 days for plants that were not fertilized to 9.08 days for plants with the maximum nitrogen dose $(240 \mathrm{~kg}$ ha $\left.^{-1}\right)$.

Regarding nitrogen sources, protected urea presented a longer phyllochron value when compared to conventional urea (Table 1). The fact that conventional urea has a faster nitrogen release rate may have influenced this response because the released nitrogen can be used more quickly used by the plant to reduce the time interval for two consecutive leaves to appear (i.e., the phyllochron).

A positive linear response of stem elongation rate (SER) to nitrogen dose was observed, with an increase of $0.0004 \mathrm{~cm} \mathrm{til}^{-1} \mathrm{day}^{-1}$ for each additional unit of nitrogen applied (Table 1). This response can be explained by the increasing nitrogen dose having favored a higher LER and a higher regrowth velocity, causing auto-shading under the grass canopy. Under conditions of low luminous intensity, tropical grasses may prioritize stem yield to allow light to reach the base of the canopy (HODGSON; SILVA, 2002). Lobo et al. (2014) verified the positive effect of nitrogen enrichment rate on SER in elephant grass 'Pioneiro' and showed an increase of $0.001 \mathrm{~cm} \mathrm{til}^{-1} \mathrm{day}^{-1}$ when there was an increase of $1 \mathrm{~kg}$ of nitrogen.

Total senescence rate (TSR) was increased linearly with increasing nitrogen dose, with an increment of $0.0007 \mathrm{~cm} \mathrm{til}^{-1} \mathrm{day}^{-1}$ for each additional nitrogen unit (Table 1). The positive effect of nitrogen on LER may have influenced TSR, as it caused greater shading of older leaves, accelerating their senescence and death. Pereira et al. (2011) reported that nitrogen fertilization also positively affected TSR in Panicum maximum 'Mombaça'.

Regarding the nitrogen sources, it was observed that plants fertilized with protected urea had higher senescence rates when compared to plants fertilized with conventional urea (Table 1). This response probably occurred because the nitrogen from the protected urea was slowly released and used more efficiently, accelerating the senescence process.

For the structural characteristics observed, there was a significant effect $(p=0.0164)$ of the interaction between sources and nitrogen doses, but only for the leaf/stem ratio (L/S). Nitrogen sources showed no independent differences $(p>0.05)$ in terms of any variable, showing that neither of the sources interfered in the plant responses to nitrogen. The doses differed $(p<0.0001)$ in terms of height, population density of tiller per clump (PDTC), and live material/dead material (LM/DM) ratio.

The L/S ratio decreased linearly in response to nitrogen dose for both sources (Table 2). This response occurred because of the fact that the increase in the production of stem biomass was greater than the production of biomass of green leaves, implying a higher stem yield than leaf yield with increasing nitrogen fertilization (Table 3). Only at a dose of $400 \mathrm{~kg} \mathrm{~N} \mathrm{ha}^{-1}$ year ${ }^{-1}$ was there a significant difference $(\mathrm{p}<0.0164)$ between the sources, at which the protected urea had a higher $\mathrm{L} / \mathrm{S}$ ratio than the conventional urea. This response probably occurred because the nitrogen of the conventional urea was released faster, and with this 
the loss of nitrogen by volatilization was higher, reducing the efficiency of nitrogen use by the plant. also observed a decreasing linear effect of nitrogen Castagnara et al. (2011), evaluating tropical grasses, fertilizer doses on $\mathrm{L} / \mathrm{S}$ ratio.

Table 2. Values of leaf/stem ratio of elephant grass 'Carajas' fertilized with different sources and doses of nitrogen.

\begin{tabular}{|c|c|c|c|c|c|c|c|}
\hline & \multicolumn{5}{|c|}{ N Doses $\left(\mathrm{kg} \mathrm{ha}^{-1}\right.$ year $\left.^{-1}\right)$} & \multirow{2}{*}{ MSE } & \multirow{2}{*}{ F Value } \\
\hline & 0 & 100 & 200 & 400 & 800 & & \\
\hline \multirow{2}{*}{$\mathrm{U}$} & $2.93 \mathrm{a}$ & $2.88 \mathrm{a}$ & $2.42 \mathrm{a}$ & $2.14 \mathrm{~b}$ & $1.91 \mathrm{a}$ & \multirow{4}{*}{0.79} & \multirow{4}{*}{$0.0164^{*}$} \\
\hline & & $\hat{\mathrm{Y}}=2.85$ & 0.00132 & $=0.864$ & & & \\
\hline \multirow{2}{*}{ PU } & $2.93 \mathrm{a}$ & $3.05 \mathrm{a}$ & $2.30 \mathrm{a}$ & $2.41 \mathrm{a}$ & $1.72 \mathrm{a}$ & & \\
\hline & \multicolumn{5}{|c|}{$\hat{\mathrm{Y}}=2.948297-0.001548 \times \mathrm{R}^{2}=0.8334$} & & \\
\hline
\end{tabular}

U: conventional urea; PU: protected urea. Means with the same lowercase letter in the column did not differ according to Tukey's test $(\mathrm{p}>0.05)$; MSE: mean standard error; *: significant difference among doses at $\mathrm{p}<0.05$.

Table 3. Values of height, PDTC, LM/DM, TFB, GLB, and GSB of elephant grass 'Carajas' under different doses of nitrogen fertilization.

\begin{tabular}{|c|c|c|c|c|c|c|c|}
\hline \multirow{2}{*}{ Variables } & \multicolumn{5}{|c|}{ N Doses $\left(\mathrm{kg} \mathrm{ha}^{-1}\right.$ year $\left.^{-1}\right)$} & \multirow{2}{*}{ MSE } & \multirow{2}{*}{ F Value } \\
\hline & 0 & 100 & 200 & 400 & 800 & & \\
\hline \multirow{2}{*}{ Height (cm) } & 64.02 & 66.07 & 68.32 & 72.51 & 75.83 & \multirow{2}{*}{0.79} & \multirow{2}{*}{$<0.0001^{*}$} \\
\hline & & $\hat{Y}=64.9114$ & +0.01478 & $\mathrm{R}^{2}=0.948$ & & & \\
\hline \multirow{2}{*}{ PDTC } & 77.00 & 81.28 & 88.31 & 92.75 & 99.78 & \multirow{2}{*}{2.49} & \multirow{2}{*}{$<0.0001 *$} \\
\hline & & $\hat{\mathrm{Y}}=79.5$ & $+0.0274 \mathrm{x}$ & $=0.9201$ & & & \\
\hline \multirow{2}{*}{$\mathrm{LM} / \mathrm{DM}$} & 9.39 & 9.69 & 9.14 & 8.37 & 7.6 & \multirow{2}{*}{1.44} & \multirow{2}{*}{$<0.0001^{*}$} \\
\hline & & $\hat{\mathrm{Y}}=9.6$ & $-0.0026 x$ & $=0.9275$ & & & \\
\hline \multirow{2}{*}{ TFB (kg DM ha'-1 year $\left.^{-1}\right)$} & 26570.1 & 36783.8 & 39158.7 & 43771.5 & 47536.0 & \multirow{2}{*}{0.84} & \multirow{2}{*}{$<0.0001 *$} \\
\hline & & $\hat{\mathrm{Y}}=3208$ & $-22.2538 x$ & $=0.7775$ & & & \\
\hline \multirow{2}{*}{ GLB (kg DM ha-1 year $\left.^{-1}\right)$} & 18278.1 & 19695.8 & 21853.7 & 23662.9 & 25984.1 & \multirow{2}{*}{0.11} & \multirow{2}{*}{$<0.0001 *$} \\
\hline & & $\hat{\mathrm{Y}}=1908$ & $+9.3759 \mathrm{x}$ & $=0.9311$ & & & \\
\hline \multirow{2}{*}{ GSB (kg DM ha-1 year $\left.^{-1}\right)$} & 9505.5 & 12803.0 & 15528.2 & 17413.3 & 20162.8 & \multirow{2}{*}{0.11} & \multirow{2}{*}{$<0.0001^{*}$} \\
\hline & & $\hat{\mathrm{Y}}=1143$ & $-12.1441 x$ & $=0.8709$ & & & \\
\hline
\end{tabular}

PDTC: population density of tiller per clump; LM/DM: live material/dead material ratio; TFB: total forage biomass; GLB: green leaf biomass; GSB: green stem biomass; MSE: mean standard error; *: significant at $\mathrm{p}<0.05$.

The height increased linearly with increasing nitrogen dose, with an increment of $0.0148 \mathrm{~cm}$ for each additional unit of nitrogen applied (Table 3). This was due to the role of nitrogen as a structural component of molecules and enzymes that are involved in the process of plant development (MALAVOLTA et al., 2006). Vitor et al. (2008), evaluating elephant grass 'Napier', also found a positive linear response of height to increasing nitrogen dose.

PDTC behaved in an increasingly linear way as the nitrogen doses were increased, presenting estimated values between 79.59 and 101.51 tillers for the treatments without fertilization and with $800 \mathrm{~kg}$ of $\mathrm{N} \mathrm{ha}^{1}$ year $^{1}$, respectively (Table 3 ). The tillering of plants that did not receive fertilization or 
received fertilization at lower doses was impaired, likely because one of the first adaptive mechanisms of grasses under conditions of nutritional restriction the reduction in the emission of new tillers (GOMIDE; GOMIDE, 1999). Evaluating elephant grass 'Napier,' Vitor et al. (2008) also observed that the tillering was higher as the doses of nitrogen increased.

A linear decrease in LM/DM ratio was observed with increasing nitrogen dose (Table 3). Based on the regression equation, values ranged between 9.61 and 7.51 for LM/DM in the non-fertilized treatment and in the one that received the highest nitrogen dose, respectively. This was an expected result, because with increased nitrogen dose there was a higher senescence rate (Table 1), which can be explained by the greater tissue renewal in the plants with increasing nitrogen dose causing more rapid death of older tissues. Pompeu et al. (2010), studying Aruana grass ( $P$. maximum 'Aruana'), verified that there was a positive linear response of the LM/DM ratio to increasing nitrogen fertilization in their study, which may have been related to the increased green leaf yield and lower amount of dead material with nitrogen enrichment.

The total forage biomass (TFB), green leaf biomass (GLB), and green stem biomass (GSB) were only significantly related to nitrogen doses. There was no significant interaction or effect of the nitrogen sources on these values. Therefore, the different urea sources did not cause different responses in the productivity of elephant grass 'Carajas'. It is important to note, however, that for the polymer-protected urea source only a single application was carried out, which results in a lower labor cost for the maintenance of the forage area.

For the TFB, a linear increase was observed with increasing nitrogen dose, with values ranging from 32087.9 to $49890.94 \mathrm{~kg}$ of DM ha- ${ }^{-1}$ year $^{-1}$ for the treatment without fertilization and with $800 \mathrm{~kg}$ of $\mathrm{N} \mathrm{ha}^{-1}$ year $^{1}$, respectively (Table 3 ). The effect of nitrogen fertilization on LER, SER, PDTC, GLB, and GSB may explain the increased TFB with the nitrogen dose. Although TFB was shown to be positively influenced by increasing nitrogen dose, the increase in TFB when the dose was increased from 400 to $800 \mathrm{~kg}$ of nitrogen was relatively low $(8.6 \%)$, which may justify not using the highest dose of nitrogen. Vitor et al. (2009), studying elephant grass 'Napier' with different nitrogen doses (100, 300,500 , and $700 \mathrm{~kg} \mathrm{ha}^{-1}$ ), observed that the highest production (29049.04 $\mathrm{kg}$ of DM ha $\left.{ }^{-1}\right)$ was obtained with the highest dose used, $700 \mathrm{~kg}$ of $\mathrm{N} \mathrm{ha}^{-1}$.

The GLB responded in a positive linear way with increased nitrogen dose, showing an increase of $9.3759 \mathrm{~kg}$ of $\mathrm{DM} \mathrm{ha}^{-1} \mathrm{year}^{-1}$ for each additional unit of nitrogen applied (Table 3). The fact that LER was positively influenced by increased nitrogen dose (Table 1) justifies the higher production of GLB in the higher doses, as there was a greater production of leaves. Fagundes et al. (2007) evaluating elephant grass 'Napier' submitted to nitrogen fertilization, reported GLB values ranging from 4.839 to 11.643 $\mathrm{kg} \mathrm{ha}^{-1}$ of DM.

For GSB, a positive linear response was observed as the nitrogen doses were increased, with an increase of $12.1441 \mathrm{~kg}$ of DM ha ${ }^{-1}$ year $^{-1}$ for each unit of nitrogen applied (Table 3). This response is explained by the fact that the increased nitrogen doses caused an increase in the SER (Table 1), which caused a higher participation of the stem fraction in the plant that contributing to increased yield of stem biomass. In the present study, it was observed using the regression equation that stem yield ranges from 11439.3 to $21154.58 \mathrm{~kg}$ of DM ha ${ }^{-1}$ year $^{-1}$ for the treatment without fertilization and with $800 \mathrm{~kg}$ of $\mathrm{N}$ ha ${ }^{1}$ year ${ }^{1}$, respectively. Martuscello et al. (2009), evaluating tropical grasses submitted to nitrogen fertilization, observed that the production of stem DM showed a positive linear response to nitrogen dose.

In terms of chemical composition, nitrogen dose had a significant effect only on the dry matter (DM) $(p<0.0001)$ and neutral detergent fiber (NDF) ( $p$ $=0.0009)$ variables. Conversely, for mineral matter $(\mathrm{MM})$ a significant effect $(\mathrm{p}=0.0050)$ of the nitrogen 
sources was observed. There was also a significant interaction between nitrogen sources and dose for the ether extract $(\mathrm{EE})(\mathrm{p}=0.0381)$ and crude protein (CP) $(\mathrm{p}<0.0001)$ variables.

The DM content showed a positive linear response to increasing nitrogen dose, with DM increasing by
$0.0017 \%$ for each additional nitrogen unit applied (Table 4). This response occurred because of the fact that nitrogen accelerates the metabolism and accelerates plant maturity, meaning that there is greater accumulation of photoassimilates and their transformation into plant organs (MENDONÇA; ROCHA, 1985).

Table 4. Dry matter (DM) and neutral detergent fiber (NDF) values of elephant grass 'Carajas' at different doses of nitrogen fertilization, and mineral matter (MM) for two different nitrogen sources.

\begin{tabular}{|c|c|c|c|c|c|c|c|}
\hline \multirow{2}{*}{ Variables } & \multicolumn{5}{|c|}{ N Doses $\left(\mathrm{kg} \mathrm{ha}^{-1}\right.$ year $\left.^{-1}\right)$} & \multirow{2}{*}{ MSE } & \multirow{2}{*}{ F Value } \\
\hline & 0 & 100 & 200 & 400 & 800 & & \\
\hline \multirow{2}{*}{ DM $(\%)$} & 18.95 & 19.28 & 19.16 & 19.63 & 20.32 & \multirow{2}{*}{0.20} & \multirow{2}{*}{$<0.0001^{*}$} \\
\hline & & $\hat{\mathrm{Y}}=18$ & +0.0017 & .9637 & & & \\
\hline \multirow{2}{*}{ NDF $(\%)$} & 61.11 & 63.24 & 66.18 & 64.16 & 63.93 & \multirow{2}{*}{0.51} & \multirow{2}{*}{$0.0009^{*}$} \\
\hline & \multicolumn{5}{|c|}{$\hat{Y}=61.7405+0.0175 x-0.000020 x^{2} R^{2}=0.6201$} & & \\
\hline & \multicolumn{5}{|c|}{ Source } & MSE & F Value \\
\hline \multirow{2}{*}{ MM (\%) } & \multicolumn{2}{|c|}{$\mathrm{U}$} & \multirow{2}{*}{\multicolumn{3}{|c|}{$9.39 \mathrm{~b}$}} & \multirow{2}{*}{0.25} & \multirow{2}{*}{$0.0050^{*}$} \\
\hline & \multicolumn{2}{|c|}{$10.39 \mathrm{a}$} & & & & & \\
\hline
\end{tabular}

U: conventional urea; PU: protected urea. Means with the same lowercase letter in the row did not differ according to Tukey's test $(\mathrm{p}>0.05)$. MSE: mean standard error; *: significant at $\mathrm{p}<0.05$.

For NDF, a quadratic response to nitrogen does was observed, with a maximum content of $65.74 \%$ observed at a dose of $437.63 \mathrm{~kg}$ of $\mathrm{N} \mathrm{ha}^{-1}$ year $^{-1}$ (Table 4). According to Vitor et al. (2009), the growth stimulus of new tissues with lower levels of structural carbohydrates in the DM caused by nitrogen fertilization may lead to a reduction in the NDF content of the plant. Mota et al. (2010) observed a reduction in NDF content in elephant grass 'Pioneiro' as nitrogen fertilization increased.

It was observed that the conventional urea resulted in higher MM content than did the protected urea (Table 4). This result was possibly due to the greater rooting of plants fertilized with conventional urea, as according to Barros (2010) the increase in the MM content is related to the plant's response to increase the root system under nutrient-limited or more disturbed conditions, thus increasing the nutrient uptake. However, no analysis was done on the roots of the plants to confirm this justification in the present study.

For EE, the two sources had different quadratic responses to increasing nitrogen dose (Table 5). There was a significant difference between the sources only at the $800 \mathrm{~kg}$ dose of $\mathrm{N} \mathrm{ha}^{-1}$ year $^{-1}$, in which protected urea resulted in a higher EE content when compared to that of conventional urea. According to Barros (2010), this response could be due to the fact that nitrogen fertilization induces an increase in the amount of pigments in the plant and, as conventional urea presents higher volatilization, this increase in pigmentation must have been impaired, reducing the EE content in the plant. Martins-Costa et al. (2008), evaluating elephant grass fertilized with $100 \mathrm{~kg}$ of $\mathrm{N} \mathrm{ha}^{1}$ year $^{-1}$, found EE values of $1.24 \%$ at 45 days, whereas Parente et al. (2012), studying elephant grass fertilized with different nitrogen doses $(0,100,200$, and $300 \mathrm{~kg}$ ha $^{-1}$ year $^{-1}$ ), found an average EE value of $5.34 \%$. 
Table 5. Ether extract (EE) and crude protein (CP) values of elephant grass 'Carajas' fertilized with different sources and doses of nitrogen.

\begin{tabular}{|c|c|c|c|c|c|c|c|}
\hline \multirow{3}{*}{ Sources } & \multicolumn{5}{|c|}{$\mathrm{EE}(\%)$} & \multirow{3}{*}{ MSE } & \multirow{3}{*}{ F Value } \\
\hline & \multicolumn{5}{|c|}{ N Doses $\left(\mathrm{kg} \mathrm{ha}^{-1}\right.$ year $\left.^{-1}\right)$} & & \\
\hline & 0 & 100 & 200 & 400 & 800 & & \\
\hline \multirow{2}{*}{$\mathrm{U}$} & $2.91 \mathrm{a}$ & $2.84 \mathrm{a}$ & $2.90 \mathrm{a}$ & $2.99 \mathrm{a}$ & $2.71 b$ & \multirow{4}{*}{0.14} & \multirow{4}{*}{0.0381} \\
\hline & & $2.8567+($ & $6 x-0.000$ & ${ }^{2} \mathrm{R}^{2}=0.6$ & & & \\
\hline \multirow{3}{*}{ PU } & $2.91 \mathrm{a}$ & $2.99 \mathrm{a}$ & $2.88 \mathrm{a}$ & $2.82 \mathrm{a}$ & $3.39 \mathrm{a}$ & & \\
\hline & \multicolumn{5}{|c|}{$\hat{Y}=2.983442-0.0010 x+0.000002 x^{2} R^{2}=0.9222$} & & \\
\hline & \multicolumn{5}{|c|}{$\mathrm{CP}(\%)$} & & \\
\hline \multirow{2}{*}{ Sources } & \multicolumn{5}{|c|}{ N Doses $\left(\mathrm{kg} \mathrm{ha}^{-1}\right.$ year $\left.^{-1}\right)$} & \multirow{2}{*}{ MSE } & \multirow{2}{*}{ F Value } \\
\hline & 0 & 100 & 200 & 400 & 800 & & \\
\hline \multirow{2}{*}{$\mathrm{U}$} & $12.09 \mathrm{a}$ & $12.74 \mathrm{a}$ & $13.69 \mathrm{a}$ & $14.31 \mathrm{a}$ & $15.45 b$ & \multirow{4}{*}{0.20} & \multirow{4}{*}{$<0.0001$} \\
\hline & & $\hat{\mathrm{Y}}=12$. & $+0.0040 \mathrm{x}$ & 0.9362 & & & \\
\hline \multirow{2}{*}{ PU } & $12.09 \mathrm{a}$ & $11.73 b$ & $13.86 \mathrm{a}$ & $14.82 \mathrm{a}$ & $16.56 \mathrm{a}$ & & \\
\hline & \multicolumn{5}{|c|}{$\hat{\mathrm{Y}}=12.0110+0.0060 \times \mathrm{R}^{2}=0.9089$} & & \\
\hline
\end{tabular}

U: conventional urea; PU: protected urea. Means with the same lowercase letter in the column did not differ according to Tukey's test $(\mathrm{p}>0.05)$; MSE: mean standard error.

$\mathrm{CP}$ values showed a positive linear response to nitrogen dose for the two sources (Table 5). This response can be explained by the fact that nitrogen is a component of many compounds that are essential for plant growth. There was a difference between the sources $(\mathrm{p}<0.05)$, but only for the doses 100 and $800 \mathrm{~kg} \mathrm{~N} \mathrm{ha}^{-1}$ year $^{-1}$. At the dose of $100 \mathrm{~kg} \mathrm{~N}^{-1}$ year ${ }^{-1}$, the conventional urea was superior in terms of CP compared to the protected urea. This was probably due to the rapid release of nitrogen from conventional urea, making the released nitrogen more readily available to the plant. At the dose of $800 \mathrm{~kg} \mathrm{~N} \mathrm{ha}^{-1}$ year $^{-1}$, the protected urea presented a higher $\mathrm{CP}$ content, possibly due to the fact that protected urea releases its nitrogen slowly, reducing losses by volatilization and favoring a most efficient use by the plant; thus, the nitrogen concentration in the plant was higher using protected urea, which contributed to the elevation of $\mathrm{CP}$ content. Valderrama et al. (2014), studying different sources of nitrogen for corn fertilization, did not find a significant difference between sources in terms of leaf nitrogen content, which was also observed for most of the doses applied in the present study. This shows that the different sources did not influence the nutritional value of the plant.

The agronomic efficiency was influenced only by nitrogen dose, and a negative linear effect of increasing dose was observed (Figure 1). The efficiency of nitrogen use by the plant is a function of various aspects, such as metabolization, absorption, and losses that occur. The variation that occurred in this study may be related to climatic conditions and availability of other elements, as these are other factors that influence the efficiency of $\mathrm{N}$ use. In both sources tested, there was a reduction in the efficiency of nitrogen use for each unit by which nitrogen dose was increased, with a reduction of $0.0548 \%$ and $0.0475 \%$ for conventional urea and protected urea, respectively. According to Sales et al. (2014), when increasing doses of some nutrient are added the greatest increase in production occurs in the first dose, and at higher levels it decreases. A similar result to the one found in the present study was observed by Vitor et al. (2009) and Silva et al. (2014), evaluating elephant grass and millet cultivars, respectively, that were submitted to different doses of nitrogen. 
Figure 1. Agronomic efficiency (AE) of elephant grass 'Carajas' as a function of the doses and sources of nitrogen fertilization.

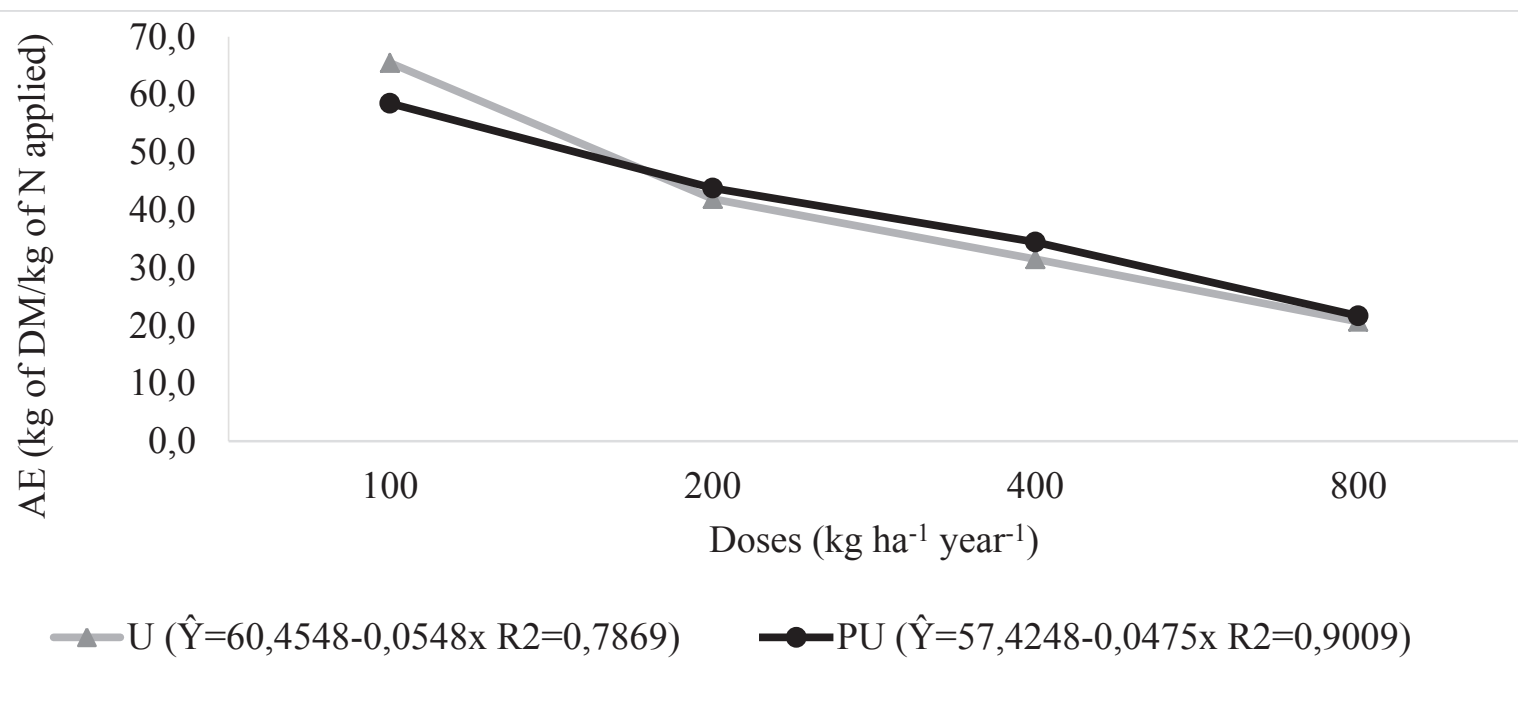

Based on the results of the present study, it can be concluded that the morphogenic, structural, and production characteristics and chemical composition of elephant grass 'Carajas' are positively influenced by increased nitrogen dose. The recommended dose for use is $400 \mathrm{~kg} \mathrm{~N} \mathrm{ha}^{-1}$ for both sources. The use of protected urea is recommended because of its slow release and single-dose application.

\section{Acknowledgments}

The authors thank the Coordination for the Improvement of Higher Education Personnel (CAPES) and the Foundation for Research Support of Piaui (FAPEPI).

\section{References}

ANDRADE, A. C.; FONSECA, D. M.; QUEIROZ, D. S.; SALGADO, L. T.; CECON, P. R. Adubação nitrogenada e potássica em capim-elefante (Pennisetum purpureum Schum. cv. Napier). Ciência e Agrotecnologia, Lavras, v. 2, p. 1643-1651, 2003. Edição Especial.

ASSOCIATION OF OFFICIAL ANALYTICAL CHEMISTS - AOAC. Official methods of analysis. $15^{\text {th }}$ ed. Washington: AOAC, 1990. 1298 p.
BARROS, I. C. Composição bromatológica de cultivares do Capim buffel em diferentes estações do ano submetidos à adubação nitrogenada. 2010. Dissertação (Mestrado em Zootecnia) - Universidade Estadual de Montes Claros, Montes Claros.

BLAYLOCK, A. Novos fertilizantes nitrogenados: o futuro dos fertilizantes nitrogenados de liberação controlada. Informações Agronômicas, Piracicaba, n. 120, p. 8-10, 2007. Edição Especial.

CASTAGNARA, D. D.; MESQUITA, E. E.; NERES, M. A.; OLIVEIRA, P. S. R.; DEMINICIS, B. B.; BAMBERG, R. Valor nutricional e características estruturais de gramíneas tropicais sob adubação nitrogenada. Archivos de Zootecnia, Córdoba, v. 60, n. 232, p. 931-942, 2011.

EUCLIDES, V. P. B.; COSTA, F. P.; MACEDO. M. C. M.; FLORES, R.; OLIVEIRA, M. P. Eficiência biológica e econômica de pasto de capim-Tanzânia adubado com nitrogênio no final do verão. Pesquisa Agropecuária Brasileira, Brasília, v. 42, n. 9, p. 1345-1355, 2007.

FAGUNDES, J. L.; FONSECA, D. M.; MISTURA, C.; SALGADO, L. T.; QUEIROZ, D. S.; MORAIS, R. V.; VITOR, C. M. T.; MOREIRA, L. M. Adubação nitrogenada e potássica em Capim-elefante cv. Napier sob pastejo rotativo. Boletim de Indústria Animal, Nova Odessa, v. 64, n. 2, p. 149-158, 2007.

FERREIRA, D. F. Sisvar: computer statistical analysis system. Ciência e Agrotecnologia, Lavras, v. 35, n. 6, p. 1039-1042, 2011. 
GOMIDE, C. A. M.; GOMIDE, J. A. Análise de crescimento de cultivares de Panicum maximum Jacq. Revista Brasileira de Zootecnia, Viçosa, MG, v. 28, n. 4, p. 675-680, 1999.

HODGSON, J.; SILVA, S. C. da. Options in tropical pasture management. In: REUNIÃO ANUAL DA SOCIEDADE BRASILEIRA DE ZOOTECNIA, 39., 2002, Recife. Anais... Recife: SBZ, 2002. p. 180-202.

JONES, C. A.; KOENG, R. T.; ELLSWORTH, J. W.; BROWN, B. D.; JACKSON, G. D. Management of urea fertilizer to minimize volatilization. Bozeman: Montana State University Extension Service, 2007. 12 p.

LOBO, B. S.; SALES, E. C. J.; REIS, S. T.; MONÇÃO, F. P.; PEREIRA, D. A.; RIQUEIRA, J. P. S.; OLIVEIRA, P. M.; MOTA, V. A. C.; ALVES, D. D. Parâmetros morfogênicos e produtividade do Capim-Pioneiro submetido a doses de nitrogênio. Semina: Ciências Agrárias, Londrina, v. 35, n. 6, p. 3305-3318, 2014.

MALAVOLTA, E. Manual de nutrição mineral de plantas. São Paulo: Ceres, 2006. 638 p.

MARTINS-COSTA, R. H. A.; CABRAL, L. S.; BHERING, M.; ABREU, J. G.; ZERVOUDAKIS, J. T.; RODRIGUES, R. C.; OLIVEIRA, Í. S. Valor nutritivo do Capim-elefante obtido em diferentes idades de corte. Revista Brasileira de Saúde e Produção Animal, Salvador, v. 9, n. 3, p. 397-406, 2008.

MARTUSCELLO, J. A.; FARIA, D. J. G.; CUNHA, D. N. F. V.; FONSECA, D. M. Adubação nitrogenada e partição de massa seca em plantas de Brachiaria brizantha cv. Xaraés e Panicum maximum x Panicum infestum cv. Massai. Ciência e Agrotecnologia, Lavras, v. 33, n. 3, p. 663-667, 2009.

MARTUSCELLO, J. A.; FONSECA, D. M.; NASCIMENTO JÚNIOR, D.; SANTOS, P. M.; CUNHA, D. N. F. V.; MOREIRA, L. M. Características morfogênicas e estruturais de capim-massai submetido à adubação nitrogenada e desfolhação. Revista Brasileira de Zootecnia, Viçosa, MG, v. 35, n. 3, p. 665-671, 2006.

MARTUSCELLO, J. A.; SILVA, L. P.; CUNHA, D. N. F. V.; BATISTA, A. C. S.; BRAZ, T. G. S.; FERREIRA, P. S. Adubação nitrogenada em capim-massai: morfogênese e produção. Ciência Animal Brasileira, Goiânia, v. 16, n. 1, p. 1-13, 2015.

MENDONÇA, J. F. B.; ROCHA, G. P. Rendimento do Capim-elefante (Pennisetum purpureum cv. Cameroom) em diferentes idades de corte. Ciência Prática, Lavras, v. 9, n. 1, p. 23-29, 1985.

MOTA, V. J. G.; REIS, S. T.; SALES, E. C. T.; ROCHA JUNIOR, V. R.; OLIVEIRA, F. G.; WALKER, S. F.; MARTINS, C. E.; CÓSER, A. C. Lâminas de irrigação e doses de nitrogênio em pastagem de capim-elefante no período seco do ano no norte de Minas Gerais. Revista Brasileira de Zootecnia, Viçosa, MG, v. 39, n. 6, p. 11911199, 2010.

OKUMURA, R. S.; MARIANO, D. C. Aspectos agronômicos da ureia tratada com inibidor de uréase. Revista do Setor de Ciências Agrárias e Ambientais, Guarapuava, v. 8, n. 2, p. 403-414, 2012.

PACIULLO, D. S. C.; GOMIDE, J. A.; RIBEIRO, K. G. Adubação nitrogenada do capim-elefante cv. Mott. 1. Rendimento forrageiro e características morfofisiológicas ao atingir 80 e $120 \mathrm{~cm}$ de altura. Revista Brasileira de Zootecnia, Viçosa, MG, v. 27, n. 6, p. 1069-1075, 1998.

PARENTE, H. N.; BANDEIRA, J. R.; RODRIGUES, R. C.; PARENTE, M. O. M.; TOSTA, X. M.; SILVA JUNIOR, O. R. Crescimento e valor nutritivo do Capimelefante submetido à adubação orgânica e mineral. Revista Brasileira de Agropecuária Sustentável, Viçosa, MG, v. 2, n. 2, p. 132-141, 2012.

PEREIRA, V. V.; FONSECA, D. M.; MARTUSCELLO, J. A.; BRAZ, T. G. S.; SANTOS, M. V.; CECON, P. R. Características morfogênicas e estruturais de capimmombaça em três densidades de cultivo adubado com nitrogênio. Revista Brasileira de Zootecnia, Viçosa, MG, v. 40, n. 12, p. 2681-2689, 2011.

POMPEU, R. C. F. F.; CANDIDO, M. J. D.; LOPES, M. N.; GOMES, F. H. T.; LACERDA, C. F.; AQUINO, B. F.; MAGALHÃES, J. A. Características morfofisiológicas do Capim-aruana sob diferentes doses de nitrogênio. Revista Brasileira de Saúde e Produção Animal, Salvador, v. 11, n. 4, p. 1187-1210, 2010.

SALES, E. C. J.; REIS, S. T.; MONÇÃO, F. P.; ANTUNES, A. B.; ALVES, D. D.; AGUIAR, A. C. R.; ANTUNES, A. P. S.; MOTA, V. A. C. Produção de forragem, características estruturais e eficiência de utilização de nitrogênio no capim-Marandu. Revista Agrarian, Dourados, v. 7, n. 25, p. 434-446, 2014.

SANTOS, D. T.; CARVALHO, P. C. F.; NABINGER, C.; CARASSAI, I. J.; GOMES, L. H. Eficiência bioeconômica da adubação de pastagem natural no sul do Brasil. Ciência Rural, Santa Maria, v. 32, n. 2, p. 437444, 2008.

SILVA, A. G.; FRANÇA, A. F. S.; MIYAGI, E. S.; DAMBROS, C. E.; LOPES, F. B. Eficiência da fertilização fosfatada e nitrogenada em cultivares de milheto. Ciência Animal Brasileira, Goiânia, v. 15, n. 2, p. 119-127, 2014.

SILVA, L. V.; CÂNDIDO, M. J. D.; PESSOA, J. P. M.; CAVALCANTE, A. C. R.; CARNEIRO, M. S. S.; SILVA, A. N. Componentes da biomassa e características 
estruturais em capim-aruana sob diferentes frequências e intensidades de desfolhação. Pesquisa Agropecuária Brasileira, Brasília, v. 50, n. 12, p. 1192-1200, 2015.

SKINNER, R. H.; NELSON, C. J. Elongation of the grass leaf and its relationship to the phyllochron. Crop Science, Madison, v. 35, n. 1, p. 4-10, 1995.

SOARES, D. A. Eficiência da adubação nitrogenada no feijoeiro sob sistema de plantio direto. 2011. Dissertação (Mestrado em Ciência do Solo) - Universidade Federal de Lavras, Lavras.

TASCA, F. A.; ERNANI, P. R.; ROGERI, D. A.; GATIBONI, L. C.; CASSOL, P. C. Volatilização de amônia do solo após a aplicação de ureia convencional ou com inibidor de uréase. Revista Brasileira de Ciência do Solo, Viçosa, MG, v. 35, n. 2, p. 493-502, 2011.

VALDERRAMA, M.; BUZETTI, S.; TEIXEIRA FILHO, M. C. M.; BENETT, C. G. S.; ANDREOTTI, M. Adubação nitrogenada na cultura do milho com ureia revestida por diferentes fontes de polímeros. Semina: Ciências Agrárias, Londrina, v. 35, n. 2, p. 659-670, 2014.

VAN SOEST, P. J.; ROBERT, R. J.; LEWIS, B. A. Methods for dietary fiber, neutral detergent fiber, and nonstarch polysaccharides in relation to animal nutrition. Journal of Dairy Science, Madison, v. 74, n. 10, p. 35833597, 1991.
VIANA, D. R.; VIEIRA, R. M. S. P.; FERRAZ NETO, S.; ALVALÁ, R. C. S. Avaliação espaço-temporal das mudanças de cobertura da terra no núcleo de desertificação de Gilbués-PI. In: CONFERÊNCIA INTERNACIONAL: CLIMA, SUSTENTABILIDADE E DESENVOLVIMENTO SUSTENTÁVEL EM REGIÕES SEMIÁRIDAS, 18., 2010, Fortaleza. Anais... Fortaleza: ICID, 2010. p. 1-18.

VILELA, L.; SOARES, W. V.; SOUSA, D. M. G.; MACEDO, M. C. M. Calagem e adubação para pastagens. In: SOUSA, D. M. G.; LOBATO, E. Cerrado: correção do solo e adubação. Planaltina: EMBRAPA Cerrados, 2002. p. 367-382.

VITOR, C. M. T.; FONSECA, D. M.; CÓSER, A. C.; MARTINS, C. E.; NASCIMENTO JUNIOR, D.; RIBEIRO JUNIOR, J. I. R. Produção de matéria seca e valor nutritivo de pastagem de Capim-elefante sob irrigação e adubação nitrogenada. Revista Brasileira de Zootecnia, Viçosa, MG, v. 38, n. 3, p. 435-442, 2009.

VITOR, C. M. T.; MARTINS, C. E.; COSER, A. C.; FONSECA, D. M.; NASCIMENTO JUNIOR, D.; RIBEIRO JUNIOR, J. I. R. Perfilhamento, altura do dossel e cobertura do solo em pastagem de Capimelefante adubados com nitrogênio e irrigado. Boletim de Indústria Animal, Nova Odessa, v. 65, n. 2, p. 147-154, 2008 . 
